\title{
High Nitrogen Costs of Dairy Production in Europe: Worsened by Intensification
}

\begin{abstract}
Intensification of agriculture has been proposed as one way of minimizing emissions per unit of product, apparently legitimizing the ongoing structural changes in agriculture. We have investigated the relationship between the farming intensity and the nitrogen $(\mathrm{N})$ dissipation by calculating the overall $\mathrm{N}$ emission factor ( $E$ : total $\mathrm{N}$ surplus per unit of $\mathrm{N}$ in the produce) from several studies of dairy farms, covering a wide range of environments and production intensities. Fundamental steps were 1) the distinction between trophic levels, mineral, plant and animal $\mathrm{N}$; and 2) the inclusion of $\mathrm{N}$ losses related to bought feed. The results show that $E$ increases significantly with the production intensity of the dairy farm. The tradition for separate optimization of the animal and crop sectors may be a reason. We suggest that the $\mathrm{N}$ pollution can be mitigated by more extensive farming, both by re-coupling crop and animal production side by side, and by keeping land under cultivation when production is reduced.
\end{abstract}

\section{INTRODUCTION}

Agriculture is the main source of reactive nitrogen (N) (1) enrichment by society, and thus the major actor contributing to the global $\mathrm{N}$ eutrophication and nitrous oxide increase $(2,3)$. Only a small part of the reactive $\mathrm{N}$ input is recovered in the agricultural produce $(4,5)$, essentially as protein. Since herbivorous animals are at a higher trophic level than plants, the production of beef and milk proteins is much less $\mathrm{N}$ efficient than the production of plant proteins $(4,6,7)$. In Europe, cattle milk and beef provide nearly $60 \%$ of the animal proteins consumed by humans (fish and seafood excluded), and nearly $42 \%$ of the world's cattle milk production occurs in Europe (8), where a rising consumption of dairy products is sustained by increasingly more intensive farming systems, making large use of purchased feed and abandoning less productive grasslands.

The Nitrate Directives (9) and the more recent Water Pollution Directives (10) oblige member countries of the European Union to take actions to reduce nitrate leaching from agriculture. The coming World Trade Organization agreements are likely to force a reduction of net exports of dairy products from European countries. This will imply a decrease in milk production in some areas. It is relevant to ask how this reduction should take place in order to mitigate to the N problem: should one reduce the intensity (produce per land area) or the size of the farmed area?

Traditionally, agricultural research has focused on the $\mathrm{N}$ efficiency of single processes, for example uptake by crops or feed utilization by animals, rather than on the efficiency of the whole system, which cannot be easily studied experimentally. However, the separate improvement of single processes may shift losses from one process to another; for example, reducing the loss of ammonia from manure storage can increase the loss during application on the field. Recently the public concern regarding $\mathrm{N}$ pollution has led to several assessments of the $\mathrm{N}$ balance of commercial and prototype farms, but the methodology used varies, and there is some confusion in the literature due to the fact that apparently equivalent definitions are given to different operative approaches. For example Brouwer et al. (11) and Oenema et al. (12) both defined the farm-gate balance (called "farm-gate budget" by the latter) as the difference between the amount of nutrient that enters and leaves the farm via the farm gate. However, although Brouwer did not include biological fixation and atmospheric deposition in the account, these were included by Oenema. Major misinterpretations arise also from the following: i) the use of gross sale rather than net sale in the calculation of the $\mathrm{N}$ efficiency and ii) the uncritical addition in the total input or in the total produce of items at different trophic levels, such as livestock, crops, and manure. Since modern animal husbandry is increasingly based on purchased feed from external enterprises, losses during off-farm feed production should be considered as well.

The purpose of this study is to contribute to the understanding of the factors that regulate the low $\mathrm{N}$ recovery observed in modern dairy farming, as a means toward an effective reduction of the total $\mathrm{N}$ dissipation. A fundamental step is the distinction between $\mathrm{N}$ at the different trophic levels: as plant nutrients, plant products, and animal products. We also found it necessary to suggest a framework for the definition of the dairy system, which includes the dairy farm and feed production outside it; to suggest relevant indicators for the $\mathrm{N}$ performance of the system and of its main compartments; and to apply this framework to published data of farm surveys and case studies in order to investigate the relationships between $\mathrm{N}$ emission and the characteristics of the dairy farms.

\section{THE DAIRY SYSTEM}

\section{Definition of the Produce}

The focus of our study is milk; however, its production is inevitably associated with meat production, which is more or less dependent on factors such as animal breed, replacement rate, and feeding. For society, the products of interest are the edible commodities: milk, meat, and edible by-products such as liver. Consumption by the farmers' families should also be considered. Although the latter is certainly important in subsistence agriculture, it is probably negligible in industrialized agriculture.

The common practice in farm N-balance studies is to report all $\mathrm{N}$ in sold live animals as produce. For conformity, the same approach is used here, and produce $\left(\boldsymbol{A}_{+\boldsymbol{w}}\right)$ is defined as the sum of the $\mathrm{N}$ in milk and livestock that qualify for human consumption. The subscript " $+w$ " reminds us that waste or inedible parts (hides, bones, digestive system etc.), which account for nearly half of the $\mathrm{N}$ in live bovine animals, are included. One g N corresponds to roughly $200 \mathrm{~g}$ milk or $40 \mathrm{~g}$ live animal, containing about $6.3 \mathrm{~g}$ proteins.

From a holistic system perspective, animal excreta represent a return-flow of nutrients from a higher (animal) to a lower (plant) trophic level. An export of animal manure implies that the $\mathrm{N}$ that would have been available to crops on the farm must be replaced by inputs through either biological fixation or synthetic fertilizer in order to maintain the same yield level, while exported manure still contributes to ammonia evapora- 
A

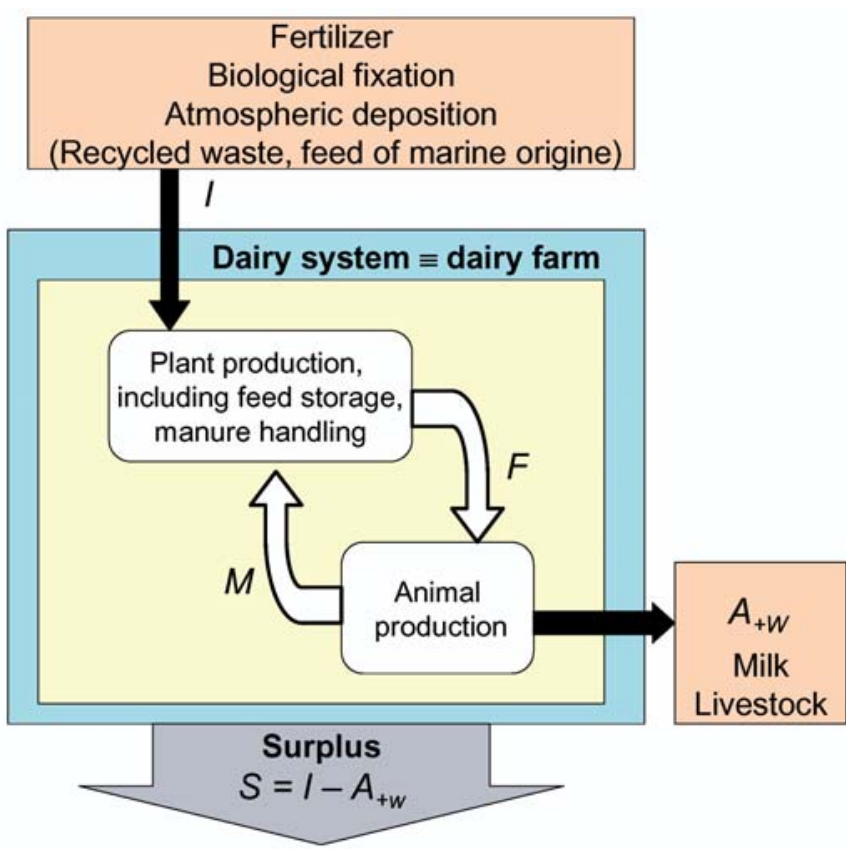

B

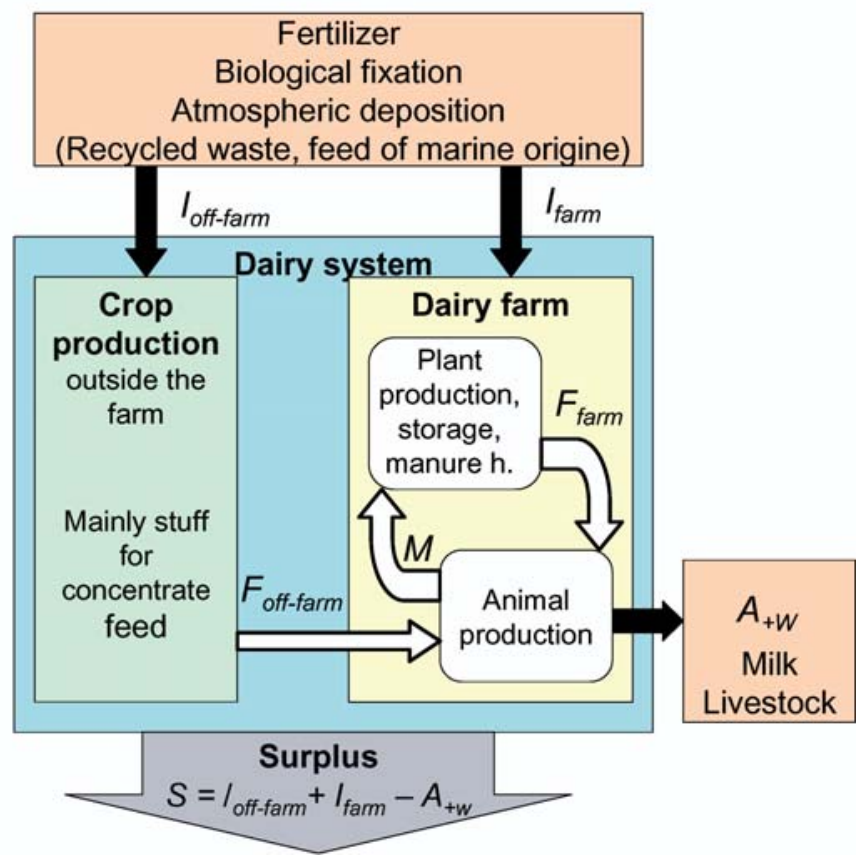

Figure 1. Schematic representation of the dairy farm system when A) all primary production (plant for feed) occurs on the farm, B) some of the feed is imported. $\boldsymbol{A}_{+w}: \mathbf{N}$ in animal produce, i.e., milk and livestock that qualify for human consumption, including $\mathbf{N}$ in nonedible parts as bones, hides, rumen content, etc.; F: total $\mathrm{N}$ in feed consumed by animals; $F_{\text {farm }}: N$ in feed produced within the farm; $F_{\text {off-farm: }} \mathrm{N}$ in purchased feed; $I: \mathrm{N}$ input; $M: \mathrm{N}$ in animal excrement (urine + dung); $S$ : $\mathbf{N}$ surplus from the milk production system, the suffixes farm and off-farm indicated $\mathrm{N}$ flows occurring on and from the dairy farm or outside it.

tion and $\mathrm{N}$ leaching elsewhere. Thus exported manure is not considered a product.

\section{Definition of the Dairy System}

We consider a dairy system with internal animal replacement and livestock production subordinated to the production of milk. All primary (plant) production required by the herd is included in the system, thus all inputs occur at the lowest trophic level, as nutrients for plant production. The soil, site of primary plant production, is included within the boundaries (Fig. 1A). This definition of the system conforms to a holistic approach, and it allows the quantification of the total $\mathrm{N}$ input per unit of produce.

The $\mathrm{N}$ inputs $(\boldsymbol{I})$ are any form of biologically available $\mathrm{N}$ entering the boundaries, basically as atmospheric deposition, biological fixation, and chemical fertilizers. But other inputs may occur, such as nitrate in irrigation water, and these should be accounted for if significant. Manure recycled within the system is not an input.

Flows of $\mathrm{N}$ within the system occur through a number of processes which occur at various times and locations on the farm, for instance, accumulation and mineralization of soil organic matter, assimilation by plants, harvesting, feed storage and processing, animal feeding and grazing, and through collection, storage, distribution, and incorporation of manure in the soils. All processes are associated with $\mathrm{N}$ losses which are not individually shown in Figure 1, but are summarized in the total surplus. An inaccuracy in the estimation of the internal flows will not affect the estimation of the surplus. However, a subdivision of the system is necessary in order to analyze the mechanisms involved in $\mathrm{N}$ recovery.

\section{The Dairy Farm is Often a Subset of the Dairy System}

Dairy farming practices in Europe range from roughage-based feeding, where only small amounts of plant products are imported, typical in alpine regions and organic farming, to feeding regimes with large use of concentrates. To give an idea of the importance that feed trade may have for a production system, in 1995 the amount of $\mathrm{N}$ in feed products imported into the Netherlands was larger than the $\mathrm{N}$ amount applied as synthetic fertilizer (13). Feed are often imported from remote regions (14) and the recycling of manure is partly disrupted (Fig. 1B). Clearly, intensive farms do not comprehend the entire production system as defined earlier.

In a real farm, the fluxes of $\mathrm{N}$ crossing the boundaries of the farm can be more complicated than shown in Figure 1B. Usually some livestock is purchased and there are imports of other plant products than feed, for example straw for bedding, and seeds. When similar products are both purchased and sold, it is possible to calculate a net input or a net produce, for example, net livestock produce is given by sale of livestock minus purchase of replacement animals. The necessary assumption is that the items considered are equivalent in terms of $\mathrm{N}$ needed for their production, and the minimum requirement for this assumption is that they are at the same trophic level. By deducting cash-crop sale from feed imports, and bought animal from sold animals, the farm $\mathrm{N}$ surplus related to the sole dairy production can be calculated. In order to make farm $\mathrm{N}$ budgets comparable, it is important to have consistent criteria for evaluating the imports of such products as fish meal and animal manure. The use of marine fish meal represents a transfer of reactive $\mathrm{N}$ from the ocean to the land, and as such it does not increase the global amount of reactive $\mathrm{N}$. However, it exploits a limited resource of animal proteins to substitute for plants proteins in feeding herbivorous animals. Therefore we consider all purchased feed proteins as plant proteins. Manure from other animal productions, for example pig or poultry, and bedding material represent a disruption of the recycle flow in the original production area, where they have to be substitutes by other inputs of $\mathrm{N}$; for this reason they have been included among inputs.

\section{N INDICATORS}

\section{N Surplus per Farmed Area and N Emission Factor}

Under a constant regime and over a long period of time, agricultural soils tend to reach a steady-state condition, where the accumulation and mineralization of the soil organic matter 
balance each other. In such a case the total $\mathrm{N}$ dissipated from an agricultural system equals the surplus $\boldsymbol{S}$ :

$$
S=I-A_{+w}
$$

(symbols as in Fig. 1A). Thus $S$ quantifies the amount of $\mathrm{N}$ that can be lost per year in the long run and represents the "potential" $\mathrm{N}$ dissipation from the system. In this sense "potential" does not mean "maximum" loss, since higher losses are likely to occur when the cultivation of a soil rich in organic matter is changed in a way that promotes rapid mineralization. There will always be yearly fluctuations in the actual $\mathrm{N}$ loss depending on the effect of weather on mineralization and on plant growth.

When $I, A_{+w}$, and $S$ are expressed as $\mathrm{N}$ amount per unit of cultivated land, $S$ can be used to calculate the N load of a region, for example in a catchment. But in order to compare the effect of alternative farm management forms on the global $\mathrm{N}$ enrichment, a second indicator was chosen: the emission factor $(\boldsymbol{E})$, i.e., the total amount of $\mathrm{N}$ dissipated per unit of $\mathrm{N}$ in the produce:

$$
E=\left(I-A_{+w}\right) / A_{+w}
$$

Eq. 2

Both $S$ and $E$ include all losses to air and to water (15) during the entire production cycle, as well as from the production of imported feed. Analogous indicators can be estimated based on the losses that occur on the dairy farm only: $S_{\text {farm }}$ and $E_{\text {farm }}$.

\section{N Costs of the Plant and Animal Sectors and Total N Cost of Animal Production}

Due to the recycling of animal manure, an improvement of the plant sector would be more effective than a relatively equal improvement of the animal sector. To clarify this point we use the $\mathrm{N}$ cost (the inverse of the $\mathrm{N}$ efficiency), because it gives a more direct appraisal of the amount of $\mathrm{N}$ needed in a process (4) and it allows a simpler notation in the following equations. The total $\mathrm{N}$ cost of animal production is the amount of reactive $\mathrm{N}$ that must enter the system as a source of $\mathrm{N}$ for plant production, in order to produce milk and animals containing one unit of $\mathrm{N}$, and it is given by the following equation:

$$
I / A_{+w}=E+1
$$

As mentioned, there are many components within the dairy system. For simplicity we group them into two sections: the plant and the animal compartments. The first one supplies feed to the animals, which in turn provide the final products, milk and livestock. In this simple division plant storage and feed processing are included in the plant compartment, as is manure handling. Since a noticeable fraction of $\mathrm{N}$ escapes as ammonia volatilization during manure storage and application to the field (16), it can be necessary to identify a distinct manure-handling compartment in specific studies of the soil $\mathrm{N}$ balance. In the following discussion, a distinction of the plant storage and manure-handling from the plant sector would complicate the notation without affecting the results substantially.

Using symbols as in Figure 1A, the $\mathrm{N}$ costs of plant production $(\alpha)$ and of the animal sector $(\beta)$ are defined by the following:

$$
\begin{gathered}
\alpha=(I+M) / F \\
\beta=F / A_{+w}
\end{gathered}
$$

where $M$ is the amount of $\mathrm{N}$ that the animal excretes (urine and solid excrements). For a given amount of produce (milk and livestock gains: $A_{+w}$ ) the necessary $\mathrm{N}$ input into plant production is given by the following equation

$$
I+M=\alpha \beta \cdot A_{+w}
$$

The amount of $\mathrm{N}$ in excrement and in feed offered to but refused by animals (when this occurs the discarded feed is often included in the manure) is given by

$$
M=A_{+w}(\beta-1)
$$

As mentioned, the emission factor is given by $E=\left(I-A_{+w}\right) /$ $A_{+w}$ (Eq. 2). Alternatively it can be found by substituting Equation (7) into Equation (6) and thus into Equation (2) when $A_{+w}=1$, which gives

$$
E=\beta(\alpha-1)
$$

If $\beta$ is changed by a factor $x$, reflecting either improved or lowered feed utilization by the animals, the surplus per unit of $\mathrm{N}$ in the product will be modified by the same factor: $x E=x \beta(\alpha-1)$, while a change of the plant $\mathrm{N}$ cost will result in a relatively greater change of the $\mathrm{N}$ surplus of the system, formally:

$$
\frac{\beta(x \alpha-1)}{\beta(\alpha-1)}=\left\{\begin{array}{lll}
<x & \text { when } & 0<x<1 \\
>x & \text { when } & x>1
\end{array}\right.
$$

In other words, if the $\mathrm{N}$ cost of plant production decreases or increases by, let's say, $10 \%$, the total surplus per unit of $\mathrm{N}$ in the produce decreases or increases by more than $10 \%$.

One should therefore be particularly observant of the possible drawbacks that a change in the animal sector may have on the $\mathrm{N}$ efficiency of the plant sector. This can be exemplified using nationwide $\mathrm{N}$-cost estimates for Norway, $\alpha=2.6$ (all plant production in agriculture) and $\beta=4.6$ (all cattle production, Table 1). The average overall $\mathrm{N}$ emission factor of cattle milk and beef production in Norway can thus be estimated around $E=4.6(2.6-1)=7.4$. Reducing either $\alpha$ or $\beta$ by $10 \%$ reduced the emission factor to 6.2 and 6.6 respectively, which shows that the improvement of the animal sector is less effective than the improvement of the plant sector. If the animal $\mathrm{N}$ cost is reduced by $10 \%$ but the plant $\mathrm{N}$ cost increases simultaneously by $7 \%$, the overall $\mathrm{N}$ cost remains unchanged: $E=4.6 \cdot 0.9(2.6 \cdot 1.07-1)=7.4$. Vice versa, if the plant $\mathrm{N}$ cost decreases by $10 \%$ and the animal $\mathrm{N}$ cost increases by $7 \%$, the $\mathrm{N}$ performance of the system is still improved to $E=4.6 \cdot 1.07(2.6 \cdot 0.9-1)=6.6$.

If the plant sector is divided into a production subsector and a storage subsector, an improvement of either would have the same overall effect as shown in Equation 9. This is because there is no or insignificant recycling flow between them (the use of silage effluents as manure is an exception to this rule).

\section{CASE STUDIES}

It is well known that the type and management of the herd has a great influence on the plant productivity, and vice versa. For example, the efficient utilization of a large pasture production in the spring depends both on whether the herd has been prepared for an abundant intake of fresh roughage and on the stocking 
Table 1. N-cost (N input/N output) of the separate plant and animal sectors from case studies of five farming systems, and nationwide estimates based on production statistics [recalculated from $(4,13)]$. Notice that all handling of animal excreta is included in the plant sector. Exclusion of the loss of ammonia that occurs before and during manure application on the field reduced the nationwide $\mathrm{N}$-costs of plant production to 2.3. See Table 2 for case description.

\begin{tabular}{|c|c|c|c|c|}
\hline \multirow[b]{2}{*}{ No. } & \multirow[b]{2}{*}{ Region } & & \multicolumn{2}{|c|}{$N$ cost } \\
\hline & & & $\begin{array}{l}\text { Animal } \\
\text { sector }\end{array}$ & $\begin{array}{l}\text { Plant } \\
\text { sector }\end{array}$ \\
\hline 3 & Southeast Norway & Prototype "Frydenhaug" & 5.15 & 1.48 \\
\hline 5 & South Germany & $\begin{array}{l}\text { Farm Talhof, average } \\
1972-1982\end{array}$ & 4.36 & 1.97 \\
\hline 15 & Southeast Norway & Prototype "Sørås" & 4.41 & 2.32 \\
\hline 16 & The Netherlands & Prototype "De Marke" & 4.42 & 1.70 \\
\hline 21 & The Netherlands & $\begin{array}{l}\text { Average specialized } \\
\text { dairy farm }\end{array}$ & 6.1 & 2.50 \\
\hline & Norway & $\begin{array}{l}\text { Production statistics } \\
1988-1991\end{array}$ & $4.6^{*}$ & 2.6 \\
\hline & The Netherlands & Production statistics, 1995 & $5.1^{\star \star}$ & 2.6 \\
\hline \multicolumn{5}{|c|}{$\begin{array}{l}\text { * Cattle, corrected for the observed lower animal yield than estimated by standard diet } \\
\text { and number of animals. }\end{array}$} \\
\hline \multicolumn{5}{|c|}{ ** Includes all kind of animals for food production } \\
\hline
\end{tabular}

rate (17). Further, the feed choice affects leaching and denitrification, for example, replacement of permanent grasslands with short-term leys and/or annual crops is likely to increase losses due to mineralization of organic matter (18). For this reason estimates of the $\mathrm{N}$ emission factor must be based on empirical observation of the entire production system. In practice one can observe farms but not the entire system, due to long-distance trade of feed.

\section{Methods}

Nitrogen balance data from 21 published surveys located in Europe, from Northern Italy to Southern Norway (latitude from $45^{\circ}$ to $60^{\circ} \mathrm{N}$ ), were used (19-31). Surveys covered conventional, integrated, and organic farms; most of them were based on averages of several farms, often over several years, and others were intensive case studies of prototype farms (Tables 2 and 3). Net farm imports and net produce were calculated by item category (i.e., plants, milk or livestock) as outlined earlier. A few studies reported small net exports of manure. This manure was not included in the produce for the reasons discussed previously. When missing, atmospheric $\mathrm{N}$ deposition has been included based on 10 years' regional averages (32).

We used data from all the surveys and case studies we found, provided that: 1) it was possible to calculate net sale of livestock and net purchase of feed; 2) the feed and fodder production on the farm covered at least $50 \%$ of the total consumption by the herd; 3) there was no net sale of plant products.

Losses outside the farm were estimated from the amount of net imported feed proteins multiplied by the average $\mathrm{N}$ cost of plant production $\alpha$.

All $\mathrm{N}$ flows (inputs, products, and surplus) are given in $\mathrm{kg} \mathrm{N}$ per hectare of agricultural land and per year. The emission factor is in $\mathrm{kg} \mathrm{kg}^{-1}$ (dimensionless).

\section{Description of the Farming Systems}

The annual milk production varied from around 3000 to 13000 $\mathrm{L}$ milk per hectare of agricultural land of the farm, and the median was about $5000 \mathrm{~L}$ milk ha $\mathrm{h}^{-1} \mathrm{y}^{-1}$. The production intensity, expressed by the net milk + livestock produce $\left(A_{+w}\right)$ per farmland area, varied from around 17 to $80 \mathrm{~kg} \mathrm{~N} \mathrm{ha}^{-1} \mathrm{y}^{-1}$, and the median value was $33 \mathrm{~kg} \mathrm{~N} \mathrm{ha} \mathrm{y}^{-1}$. The lowest production intensities were found for farm systems in the alpine region and some organic farms. The highest intensities were in the Netherlands, Belgium, Denmark, and on a Norwegian prototype farm. The ratio of the milk $\mathrm{N}$ produce to the livestock $\mathrm{N}$ produce varied from almost 2 to 8 (excluding a prototype farm, with no internal recruitment), and the median was around

Table 2. Location, management (C: conventional, I: integrated, O: organic), name of the prototype or number of commercial farms included and period of the survey considered, as well as some farm characteristics. Distinction in more or less intensive farm groups is according to the authors of the surveys.

\begin{tabular}{|c|c|c|c|c|c|c|c|c|c|}
\hline Reference & No. & Region & & Management and data source & $\begin{array}{c}\text { Farm } \\
\text { area ha }\end{array}$ & $\begin{array}{c}\% \\
\text { grassland }\end{array}$ & $\begin{array}{l}\text { Cows } \\
\mathrm{ha}^{-1}\end{array}$ & $\begin{array}{l}\text { kg or } L \text { milk } \\
\text { dairy } \operatorname{cow}^{-1}\end{array}$ & $\begin{array}{l}\text { kg or L } \\
\text { milk ha }{ }^{-1}\end{array}$ \\
\hline (19) & 1 & Austria & $\mathrm{O}$ & $\mathrm{n}=40,1998$ & 20 & & & 4710 & $3000^{*}$ \\
\hline (19) & 2 & Austria & 1 & $\mathrm{n}=51,1998$ & 17.8 & & & 4650 & $2703^{\star}$ \\
\hline (20) & 3 & South-East Norway & $\mathrm{O}$ & Prototype "Frydenhaug" 1999/00-2001/02 & 27.4 & 60 & 0.69 & 4566 & 3161 \\
\hline (19) & 4 & Austria & $\mathrm{C}$ & $\mathrm{n}=66,1998$ & 23.5 & & & 6095 & $3574^{\star}$ \\
\hline (21) & 5 & South Germany & $\mathrm{O}$ & $\begin{array}{l}\text { Comm. farm Talhof, biodynamic since } 1929 \text {, } \\
\text { 1972-1982 }\end{array}$ & 48.3 & & 0.56 & 4540 & 2539 \\
\hline$(22)$ & 6 & North-West Germany & $\mathrm{O}$ & $\mathrm{n}=6,1995 / 1996-1997 / 1998$ & 65 & 77 & 0.74 & 5340 & 3769 \\
\hline (23) & 7 & France, Bretagne & $\mathrm{C}$ & $\mathrm{n}=43,1996-1997$, lowest surplus & & & & 6330 & 5040 \\
\hline (22) & 8 & North-West Germany & $\mathrm{C}$ & $\begin{array}{l}\mathrm{n}=10,1995 / 1996-1997 / 1998 \\
25 \% \text { best farms }\end{array}$ & 79 & 73 & 0.73 & 6651 & 5029 \\
\hline (24) & 9 & West Norway & $\mathrm{C}$ & $\begin{array}{l}n \approx 20 \text { each year, } 1990-1998 \\
25 \% \text { least intensive }\end{array}$ & & & 0.64 & 6695 & 4300 \\
\hline$(25,26)$ & 10 & Denmark & $\mathrm{O}$ & $\mathrm{n}=14,1989-1990$ & 67 & & 0.8 & 6700 & 5600 \\
\hline$(27)$ & 11 & North Italy, Piemonte & $\mathrm{C}$ & $\mathrm{n}=23,1992$ & 34 & 45 & & & 3406 \\
\hline (23) & 12 & France, Bretagne & C & $\mathrm{n}=42,1996-1997$, middle surplus & & & & 6682 & 5685 \\
\hline (28) & 13 & Wales & $\mathrm{O}$ & Prototype "Ty Gwyn" 1995-1998 & 63 & 93 & 1.3 & 5430 & 6895 \\
\hline (22) & 14 & North-West Germany & $\mathrm{C}$ & $\begin{array}{l}n=39, \text { including } 10 \text { "best", } \\
1195 / 1996-1997 / 1998\end{array}$ & 75 & 73 & 0.88 & 6911 & 6139 \\
\hline (29) & 15 & South-East Norway & C & Prototype "Sørås", 1998/1999-2000/2001 & 31.4 & 86 & 1.6 & 5817 & 9215 \\
\hline (30) & 16 & The Netherlands & C & Prototype "De Marke" 1993/1994-1995/1996 & 55 & 55 & 1.45 & 8200 & 11890 \\
\hline (23) & 17 & France, Bretagne & C & $\mathrm{n}=43,1996-1997$, largest surplus & & & & 6813 & 6210 \\
\hline (24) & 18 & West Norway & $\mathrm{C}$ & $\begin{array}{l}n \approx 20 \text { each year, } 1990-1998 \\
25 \% \text { least intensive }\end{array}$ & & & 0.89 & 6627 & 5890 \\
\hline$(25,26)$ & 19 & Denmark & C & $\mathrm{n}=16,1989-1990$ & 53 & & 1.09 & 7493 & 8200 \\
\hline (31) & 20 & Belgium, Vlaanderen & $\mathrm{C}$ & $\mathrm{n}=48,1991-1992$ & 31 & 64 & & & 10566 \\
\hline (30) & 21 & The Netherlands & C & $\begin{array}{l}\text { Average specialized dairy farm, } \\
\text { 1993/1994-1994/1995 }\end{array}$ & & 90 & 2.31 & 5540 & 12798 \\
\hline
\end{tabular}


Table 3. $\mathrm{N}$ inputs into the farm and $\mathrm{N}$ in milk and net livestock sale $A_{+w}\left(\mathrm{~kg} \mathrm{~N} \mathrm{ha}^{-1}\right.$ year $\left.{ }^{-1}\right)$. Apparent $\mathrm{N}$ cost of the farm $\left[\left(I_{\text {farm }}+F_{\text {off-farm }}\right) / A_{+w}\right]$. See Table 2 for case description.

Input, $\mathbf{k g ~ N ~ h a}^{-1}$

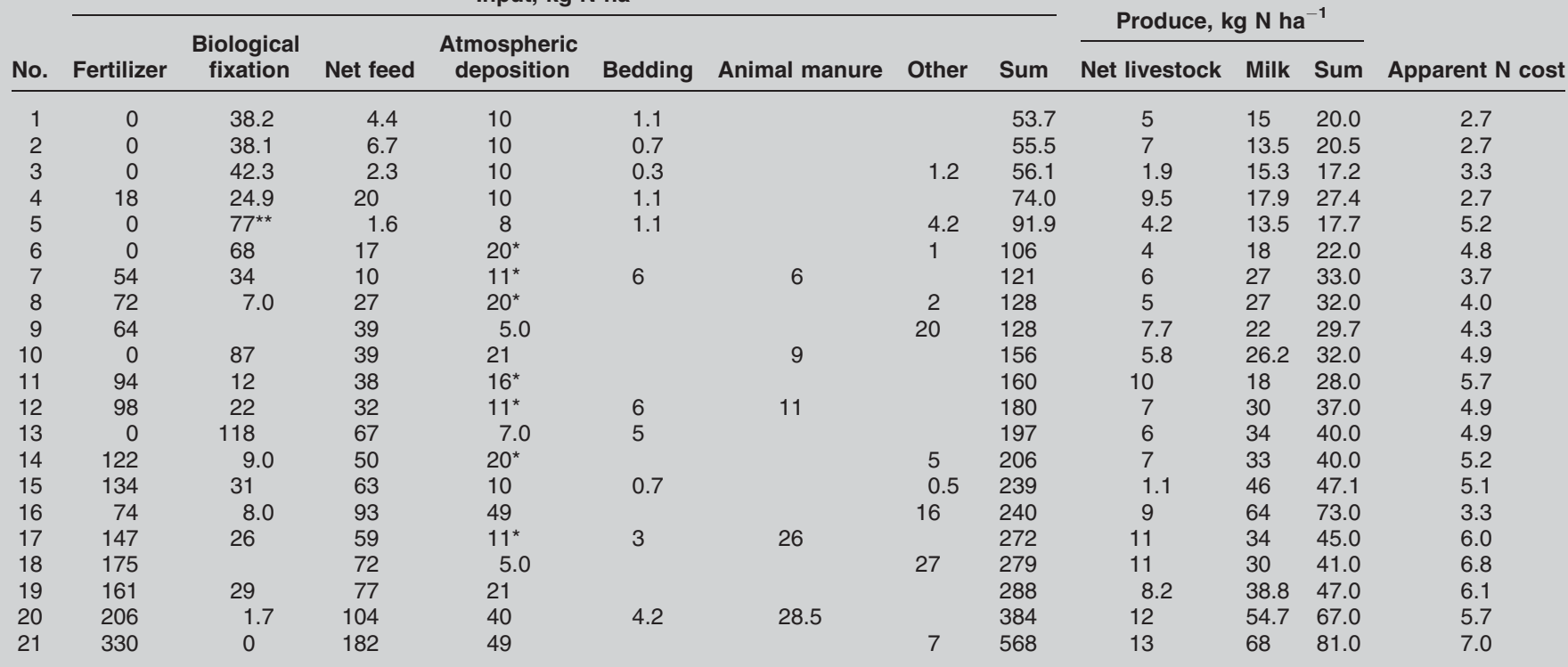

*: Based on ten years averages (30).

**: All inputs minus all outputs (incl. leaching and ammonia volatilization) mentioned by Kaffka and Koepf (19)

4.4. The $\mathrm{N}$ input into the farm through net purchased feed varied from less than $2 \mathrm{~kg} \mathrm{ha}^{-1} \mathrm{y}^{-1}$ to $100 \mathrm{~kg} \mathrm{ha}^{-1} \mathrm{y}^{-1}$, except for a survey of commercial farms in the Netherlands, where purchased feed accounted for more than $180 \mathrm{~kg} \mathrm{~N}^{-1} \mathrm{y}^{-1}$; the median was about $40 \mathrm{~kg} \mathrm{~N} \mathrm{ha} \mathrm{y}^{-1}$.
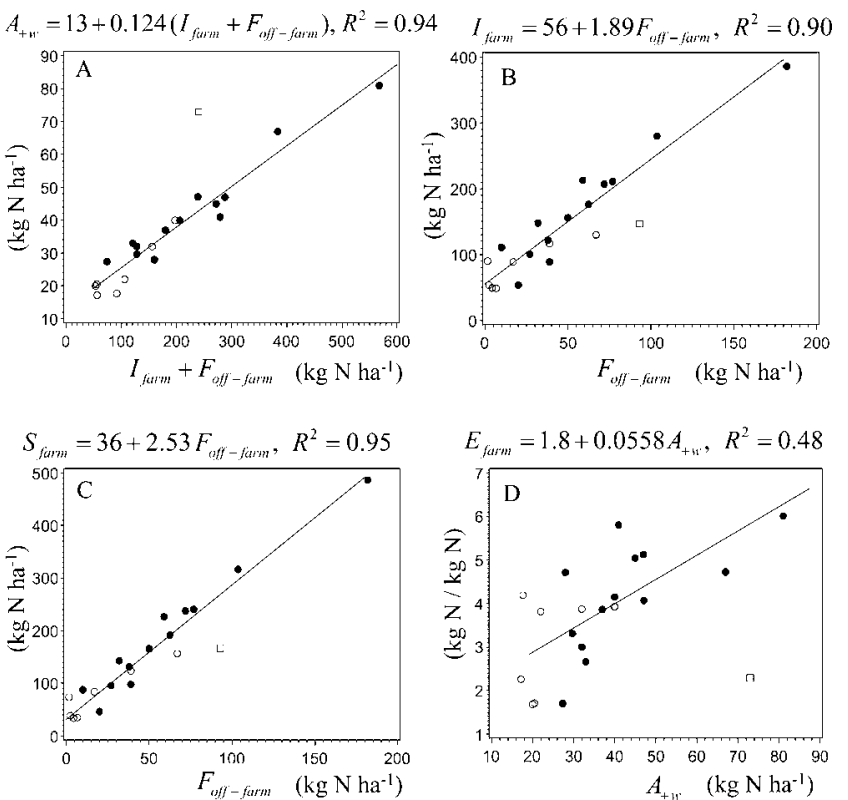

Figure 2. Relationship between $A$ ) net milk and livestock produce $\left(\boldsymbol{A}_{+w}\right)$ and net $\mathrm{N}$ input into the farm $\left(\boldsymbol{I}_{\text {farm }}+\boldsymbol{F}_{\text {off-farm }}\right)$; B) nonfeed $\mathrm{N}$ input to the farm $\left(I_{\text {farm }}\right)$ and $N$ input as feed $\left.\left(F_{\text {off-farm }}\right) ; C\right) N$ surplus at the farm level $\left(S_{\text {farm }}\right)$ and $N$ input as feed $\left(F_{\text {off-farm }}\right)$; D) apparent $N$ emission factor at the farm $\left(E_{\text {farm }}, \mathrm{kg} \mathrm{N} / \mathrm{kg} \mathrm{N}\right)$ and animal produce per unit of land area of the dairy farm $\left(A_{1}, \mathrm{~kg} \mathrm{~N}^{-1}\right)$. Data in $\mathrm{A}, \mathrm{B}$, and $\mathrm{C}$ are annual $\mathrm{N}$ flows in $\mathrm{kg} \mathrm{N} \mathrm{ha}^{-1}$. Open circle: organic or integrated farm; closed circle: conventional farm; square: "De Marke" (28), excluded from the regressions. All intercept and slope estimates are statistically significant $(P<0.02)$. Notice that the emission factor also includes losses to water.

\section{Production and N Loss from the Dairy Farms}

The produce $A_{+w}$ ( $\mathrm{N}$ in milk and livestock per hectare of dairy farm) was strongly related to the total $\mathrm{N}$ input to the farm as purchased feed and other forms of reactive $\mathrm{N}\left(F_{\text {off-farm }}+I_{\text {farm }}\right.$, see Figure 1 for the use of abbreviations), but only about $12 \%$ of the $\mathrm{N}$ input was found in the produce (Fig. 2A). Thus the surplus at the farm increased markedly with the total input to the farm (Table 4). The produce $A_{+w}$ was equally strongly related to the feed import alone $\left(A_{+w}=20+0.36 F_{\text {off-farm }}, \mathrm{R}^{2}=0.92\right)$.

There was a clear dependency between net feed imports ( $F_{\text {off-farm }}$, purchase minus sale) and other $\mathrm{N}$ imports to the farm $\left(I_{\text {farm }}, \mathrm{kg} \mathrm{N} \mathrm{ha}^{-1} \mathrm{y}^{-1}\right)$. If $\mathrm{N}$ in animal manure is used efficiently, lower inputs of other $\mathrm{N}$ supplies are to be expected as feed import increases. Figure 2B shows that this was definitely not the case. Farms with largest net import of feed $\left(F_{\text {off-farm }}\right)$ had also largest nonfeed imports $\left(I_{\text {farm }}\right)$, nearly $2 \mathrm{~kg} \mathrm{~N} \mathrm{ha}^{-1} \mathrm{y}^{-1}$ more $\mathrm{N}$ per $\mathrm{kg} \mathrm{N} \mathrm{ha}^{-1} \mathrm{y}^{-1}$ imported feed, and the $\mathrm{N}$ surplus of the

Table 4. Results from the regression of the farm surplus $\left(S_{\text {farm }}\right)$, versus total input into the farm, and results of regression of the apparent $\mathrm{N}$ emission at the farm $\left(E_{\text {farm }}=S_{\text {farm }} / A_{+w}\right)$ versus the $\mathrm{N}$ surplus at the farm per unit of land area $\left(S_{\text {farm }}\right)$; the nonfeed $N$ input to the farm per unit of land area $\left(I_{\text {farm }}\right)$; the total $N$ input to the farm $\left(I_{\text {farm }}+F_{\text {off-farm }}\right)$ per unit of land area; the feed import per unit of farm land area $\left(F_{\text {off-farm }}\right)$; and the $N$ in the produce per unit of farm land area (milk + livestock, $A_{+w}$ ). The prototype farm "De Marke" (28) was excluded from the regression. Number of observations: 20. In the last line the average for Dutch commercial farms was also eliminated. All slope estimates were statistically significant $(P<0.025)$. Notice that the emission factor includes losses to water.

\begin{tabular}{lcc} 
& $\boldsymbol{n}$ & $\boldsymbol{R}^{\mathbf{2}}$ \\
\hline$S_{\text {farm }}=-14+0.87 \cdot\left(I_{\text {farm }}+F_{\text {off-farm }}\right)$ & 20 & 0.99 \\
$E_{\text {farm }}=2.3+0.0097 \cdot S_{\text {farm }}$ & 20 & 0.68 \\
$E_{\text {farm }}=2.0+0.013 \cdot I_{\text {farm }}$ & 20 & 0.69 \\
$E_{\text {farm }}=2.2+0.0083 \cdot\left(I_{\text {farm }}+F_{\text {off-farm }}\right)$ & 20 & 0.66 \\
$E_{\text {farm }}=2.7+0.023 \cdot F_{\text {off-farm }}$ & 20 & 0.56 \\
$E_{\text {farm }}=1.8+0.056 \cdot A_{+w}$ & 20 & 0.48 \\
$E_{\text {farm }}=1.6+0.060 \cdot A_{+w}$ & 19 & 0.38
\end{tabular}



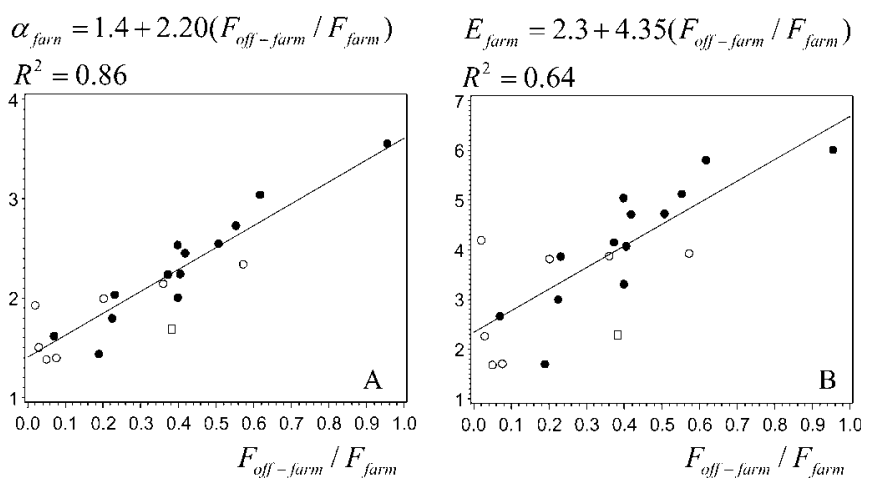

Figure 3. Relationship between A) N cost of the plant sector $\alpha_{\text {farm }}$ (including the manure sector, see text for explanation) and the ratio of the imported feed to the feed produced on the farm; B) the apparent $\mathrm{N}$-emission factor at the farm $\left(E_{\text {farm }}, \mathrm{kg} \mathrm{N} / \mathrm{kg} \mathrm{N}\right)$ and the ratio of the imported feed to the feed produced on the farm. See text for the assumption used in order to estimate the amount of feed produced on the farm. Open circle: organic or integrated farm; closed circle: conventional farm; square: "De Marke", excluded from the regressions. All intercept and slope estimates are statistically significant $(P<0.02)$. Notice that the emission factor includes losses to water.

farm per land area $\left(S_{\text {farm }}\right)$ increased strongly with $F_{\text {off-farm }}$, about $2.5 \mathrm{~kg}$ more surplus per additional $\mathrm{N} \mathrm{kg}$ in purchased feed (Fig. 2C).

The emission factor for the $\mathrm{N}$ loss from the farm only $\left(E_{\text {farm }}\right.$, $\mathrm{kg} \mathrm{N}$ per $\mathrm{kg} \mathrm{N}$ in the produce) was about equally strongly related (Table 4$)$ to the surplus per farm area $\left(S_{\text {farm, }} \mathrm{kg} \mathrm{N} \mathrm{ha}^{-1}\right)$, to the nonfeed import $\left(I_{\text {farm }}\right)$, as well as to the total $\mathrm{N}$ input to the farm $\left(I_{\text {farm }}+F_{\text {off-farm }}\right)\left(\mathrm{R}^{2}=0.68,0.69\right.$, and 0.66 , respectively), and to a lesser extent to the net imports of feed $\left(F_{o f f-f a r m}, \mathrm{R}^{2}=0.56\right)$ and to the animal produce per land area of the farm $\left(A_{+w}\right),\left(\mathrm{R}^{2}=0.48\right.$, Fig. 2D). Although the intensity of animal production accounted for only $48 \%$ of the total variation, this effect was statistically significant $(\mathrm{P}<0.025$, Table 4).

Milk production was expected to be more $\mathrm{N}$ efficient than meat production; there was, however, absolutely no relationship between the $\mathrm{N}$ surplus (either $S_{\text {farm }}$ or $E_{\text {farm }}$ ) and the ratio of livestock / milk produce.

There was no distinction in any of the relationships studied between farm systems in different parts of Europe, apart from that due to production intensity. There was also no clear distinction between organic and conventional farms, but the former tended to have less $\mathrm{N}$ input per unit of land area and thus lower surplus. The only exception was the Dutch prototype farm "De Marke," which had a clearly higher production relative to the $\mathrm{N}$ input level (Fig. 2A, se also Figs. 2D and 4). Appropriate statistics (studentized residual $>2$, large DFFIT) revealing a strong influence on the predicted value (See pages 1418-1419 in: 33) indicated that "De Marke" was a clear outlier, and therefore it was excluded from all regression equations. The average of the Dutch commercial farms around "De Marke" had much higher inputs and higher production than all other cases considered, and could in some cases have a high leverage on the regression. However, the omission of this observation had at most moderate effect on the estimates of the regression lines (see the two last rows in Table 4), consequently the average of Dutch commercial farms was included in the calculations. All regression lines were thus based on 20 observations.

Displacing some of the feed production out of the farm can in theory reduce the surplus at the farm, since some of the losses connected to feed production are located outside the farm. Alternatively, imported feed can be used to intensify the animal production on the farm above the level supported by the
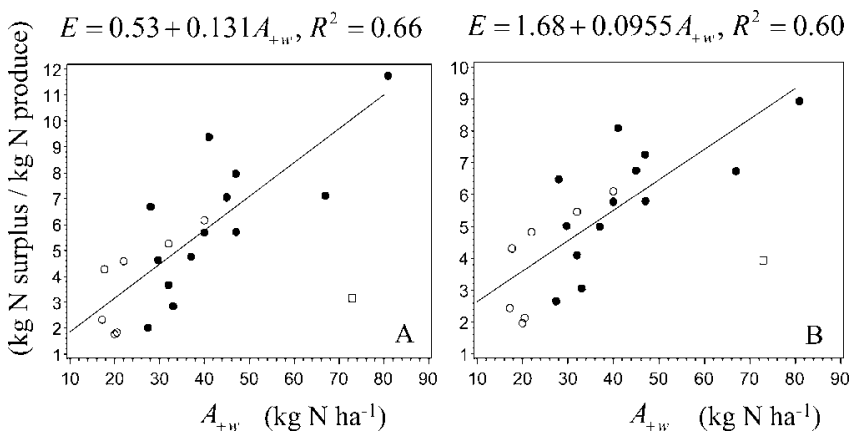

Figure 4. The $\mathrm{N}$-emission factor generated during the entire production cycle per unit $\mathrm{N}$ of produce $(E)$, assuming that the $\mathrm{N}$ cost of plant production ( $\alpha$ ) outside the farm is equal to $A$ ) the plant $N$ cost on the farm $\left(\alpha_{\text {farm }}\right)$, estimated assuming $\beta=4.6$ ) or $B$ ) a constant value $\alpha=2.3$. Open circle: organic or integrated farm; closed circle: conventional farm; square: "De Marke", excluded from the regressions. In A) the estimate of the intercept is not statistically significant. All other parameters are statistically significant. If the two observations with largest share of imported feed as well as with largest produce are eliminated, the slope of the regression line in B) becomes equal to that in A). Notice that the emission factor includes losses to water.

productivity of the soil, leading to a greater load of animal manure and thus lowering the efficiency of the plant compartment. We tested this hypothesis by regressing the estimated $\mathrm{N}$ cost of the plant compartment $(\alpha)$ against the ratio $F_{\text {off-farm }} / F_{\text {farm }}$. A high ratio indicates that a large amount of feed was imported relative to what was produced on the farm. Unfortunately, most of the studies had no information about the actual plant production on the farm, which in the case of pasture is awkward and burdensome to assess in farm surveys. An estimate was calculated as $F_{\text {farm }}=\beta A_{+w}-F_{\text {off-farm }}$. An average value of $\beta=4.6$ was used based on nationwide averages and on observation from some prototype farms (Table 1), and $\alpha_{\text {farm }}$ was estimated as $\alpha_{\text {farm }}=\left[I_{\text {farm }}+(\beta-1) A_{+w}\right] / F_{\text {farm }}$ (adapted from Eqs. 4 and 7).

The results indicate that as the amount of imported feed increases from nil to nearly the same amount produced on the farm, the $\mathrm{N}$ cost of the plant sector (including feed storage and manure handling) increases from a minimum value of 1.4 to 3.5 (Fig. 3A, using a value of $\beta=4.4$ did not notably affect the estimates). This signifies that the intensification of the animal production relative to the local soil productivity has a strong negative effect on the efficiency of the plant sector of the farm. This is also reflected by the relationship between the emission factor for the activity on the farm $\left(E_{\text {farm }}\right)$ and the ratio of the imported to the home-produced feed $\left(F_{\text {off-farm }} / F_{\text {farm }}\right.$, Fig. $\left.3 \mathrm{~B}\right)$. If the total efficiency of the processes within the dairy farm was unaffected or improved by the use of imported feed, then $E_{\text {farm }}$ should decrease as the amount of imported feed increases, because some of the $\mathrm{N}$ surplus connected to primary production is excluded from the input to the farm: $S_{\text {off-farm }}=I_{\text {off-farm }}-F_{\text {off-farm }}$. This was not the case for the present collection of surveys from throughout Europe.

\section{N Emission from the Whole Dairy System}

In order to asses the efficiency of the whole production cycle, it is necessary to estimate losses outside the farm. This can be done by applying the $\mathrm{N}$ cost of the plant compartment of the farm also to the net imported feed: $S_{\text {off-farm }}=\left(\alpha_{f a r m}-1\right) F_{\text {off-farm }}$. Alternatively it can be observed that the off-farm feed is mainly based on energy- and protein-rich annual crops with no use of animal manure, which implies that the off-farm $\mathrm{N}$ cost is likely to be higher than that found in low-input, roughage-based farms (those with low $\alpha_{\text {farm }}$ ), but lower than for intensive farms with 
high loads of manure (those with high $\alpha_{f a r m}$ ). Furthermore, long-distance trade makes the local $\alpha_{\text {farm }}$ irrelevant for purchased feed. These considerations suggest the use of a constant off-farm cost of plant production. To illustrate the significance of including losses outside the farm, both methods were used in order to estimate the global surplus per unit of $\mathrm{N}$ in the produce. Both methods resulted in a better correlation of the overall emission factor $E$ with the farming intensity than when only farm surpluses $\left(E_{\text {farm }}\right)$ were considered (compare Fig. 4 and Fig. 2D). The emission factor $(\mathrm{kg} \mathrm{N} / \mathrm{kg} \mathrm{N})$ increased from about 2-3 to 9-12 as $A_{+w}$ increased from 20 to $80 \mathrm{~kg} \mathrm{~N} \mathrm{ha}^{-1}$. Thus, the net $\mathrm{N}$ cost for an amount of produce containing $1 \mathrm{~g}$ of $\mathrm{N}$ (approximately $6.37 \mathrm{~g}$ milk proteins, roughly $200 \mathrm{~g}$ milk) increased from about 3-4 to 10-13 g (see Eq. 3 for the relation between emission factor and total $\mathrm{N}$ cost). The system efficiency $A_{+w} / I$ can be calculated as $1 /(\mathrm{E}+1)$. Applying this equation to the regressions line in Figure 4, the system efficiency decreased from $0.24-0.22$ to $0.10-0.08$ from the less intensive to the most intensive production systems. Notice that only the area of the dairy farm is considered in the definition of $A_{+w}$. Thus the effective productivity of the whole system $\left[P=\left(A_{+w} \cdot\right.\right.$ land onfarm) / (land-on-farm + land off-farm)] was lower than revealed by looking at dairy farms only, and the ratio $P / A_{+w}$ decreased as $A_{+w}$ increased, since the latter was strongly positively correlated with $F_{\text {off-farm }}$.

\section{DISCUSSION}

\section{Consequences for the Global N Use of Fertilizer}

The following calculation may help to illustrate the importance of milk production in a global context.

Milk production in Europe is presently around $210 \mathrm{Tg}$ annually $\left(1 \mathrm{Tg}=10^{12} \mathrm{~g}\right)(8)$, containing roughly $1 \mathrm{Tg} \mathrm{N}$. Assuming a general production intensity as for the median of the case studies $\left(33 \mathrm{~kg} \mathrm{~N}^{-1} \mathrm{y}^{-1}\right)$, and using the median of the ratio of the products milk $N /($ milk + livestock $\mathrm{N})=0.8$, the $\mathrm{N}$ cost of European milk production can be estimated from the regression line of Figure 4A and Equation 3 as $1 \cdot 0.8(1+0.53+$ $0.13 \cdot 33)=4.7 \mathrm{Tg} \mathrm{N}$, equivalent to about $35 \%$ of the European annual use of fertilizer $(13.4 \mathrm{Tg})(8)$. The real value might be higher, due to the presence of landless farming (34).

If all kinds of dairy production were confined on smaller areas so that the amount of produce remained constant, but $A_{+w}$ increased by $10 \mathrm{~kg} \mathrm{~N} \mathrm{ha}^{-1}$ irrespective of the starting conditions, the annual consumption of fertilizer would increase by $1 \cdot 0.8(0.13 \cdot 10)=1 \mathrm{Tg} \mathrm{N}$ in order to sustain milk production alone. Since the associated meat production would also be intensified, the total use of fertilizer would increase by 1 . $(0.8+0.2)(0.13 \cdot 10)=1.3 \mathrm{Tg} \mathrm{N}$ (or more if fertilizer must compensate for a reduction in biological fixation). This is about one-tenth of the present use of fertilizer in Europe.

\section{Definition of Dairy System and Produce}

The distinction between trophic levels and the identification of the final products delivered to society does not affect the estimates of nutrient surplus on the farm, but it is critical for a correct assessment of the $\mathrm{N}$ emission factor. Confounding crop and animal products makes the analysis nebulous. This is one reason why many authors have not found as clear relationships between the $\mathrm{N}$-use efficiency and production intensity as shown in this study (e.g. 35, 36). Recently Schröder et al. (37) exemplified the consequences of dividing a single dairy farm into two specialized enterprises, one for feed production, and the other for animal management. This is clearly analogous to the identification of a plant and an animal sector, each having higher $\mathrm{N}$-use efficiency than that of the overall system. Thus, farm specialization may result in apparent better use efficiency (within each of the specialized production units), unless careful attention is paid to the distinction between intermediary (feed) and final products (milk and meat).

The amount of $\mathrm{N}$ in bought animals may appear trivial relative to the total input into the farm, but this information is essential for estimating the net produce and thus correctly assessing the emission factor.

Meat and milk have been considered together because they are products at the same trophic level, and meat is a necessary companion product of milk. However, from a nutritional point of view, while milk is wholly edible, just above half the $\mathrm{N}$ in live animals is lean meat and by-products suitable for human consumption. Further analysis attempting to compare systems on the basis of their contribution to human diet should take this difference into account.

The conversion of $\mathrm{N}$ from plant material to milk protein is usually more efficient than conversion to meat proteins (38). For this reason, an increasing $\mathrm{N}$ efficiency and a decreasing $\mathrm{N}$ surplus were expected as the share of milk increased relative to livestock. The reason why this was not so is not clear and deserves further studies. A more stringent definition of the animal life cycle to be included in the system may help in this respect.

Slaughter waste and dairy by-products may reenter the production cycle as feed products and soil additives, this may solve local pollution problems but has relatively little effect on the input of new reactive $N$. Inputs could be reduced by $1-2 \%$ if all whey from dairies was recycled, and by a further $2 \%$ by recycling bonemeal as feed (4). The latter, however, is currently totally banned within the EU. Neglecting these possible backflows has thus minimal consequences for this study.

\section{Indicators}

The most commonly used indicator for $\mathrm{N}$ dissipation from agriculture is the amount of $\mathrm{N}$ dissipated per area of cultivated land; this has many advantages when calculating the pollution load on a geographically defined area. It is, however, not necessarily adequate to describe the overall $\mathrm{N}$ efficiency of the production system. For example, relatively equal reductions of both input and produce give a lower dissipation load, but do not reduce the $\mathrm{N}$ cost ( $\mathrm{N}$ input per unit of produce). The efficiency must be improved if society shall abate the global $\mathrm{N}$ pollution without reducing the supply of milk and meat. The emission factor ( $E$ : the $\mathrm{N}$ surplus during the entire production cycle per unit of $\mathrm{N}$ in the produce) is a suitable indicator in this respect, since it can be applied to estimate the global $\mathrm{N}$ loss, including the amount concealed by the trade of intermediary products, for a given demand by society.

The surveys included ranged in location from $45^{\circ}$ to $60^{\circ} \mathrm{N}$ of latitude. Considering the wide range, it is surprising that the linear relationships between the surplus indicators $\left(S_{\text {farm }}\right.$ or $E$ ) and the production level fitted so well to farming systems that are expected to differ greatly in environmental conditions, both in soils and climate. A larger number of observations may help to reveal possible regional and management effects not exposed in this study. For example, Grignani (27) found a similar regression line but a less steep slope for the $\mathrm{N}$ surplus versus the feed import $\left(S_{\text {farm }}=82+0.75 F_{\text {off-farm }}, \mathrm{R}^{2}=0.87\right.$, compare with Fig. 2C) of single farms in Northern Italy. However, the strong dependency of the surplus (both $S_{\text {farm }}$ and $E$ ) on the level of dairy production deserves the joint attention of both agronomists and animal scientists.

The prototype farm "De Marke" was the only case that did not fit in the observed relationships. The management of this 
farm has been conceived by close cooperation of different expertises (regarding crop, soil, animal, economy) and farmers, aiming at the abatement of the total nitrate loading of the aquifer (30). Aftereffects of previously accumulated organic $\mathrm{N}$ in the soil may have contributed to the positive results. However, even if the efficiency of this farm should stabilize at a somewhat lower level than measured during the first years of improved management, its performance would still be remarkable, and it demonstrates that considerable improvement can be achieved.

\section{Plant versus Animal Sector}

The calculated $\mathrm{N}$ costs of plant production $\left(\alpha_{\text {farm }}\right)$ varied over a very wide range. Nevertheless, apart from the lowest values, they are higher than usually found in field experiments plus estimated ammonia volatilization. The reason for this is that losses during feed handling and storage are included, as well as a variety of factors important in real life situation, that are usually removed from experimental conditions. Among these are reduced yield in border areas, losses during and after harvesting with farm equipment, as well as the fact that exuberant production of roughages may remain unutilized. Steinshamn et al. (20) found that about $40 \%$ of $\mathrm{N}$ in harvestable biomass, weighted over all crops and grazed land on the farm, was lost before intake by the animal. In the prototype farm "De Marke", which was distinguished by a very high $\mathrm{N}$ efficiency relative to the level of production, the storage and grazing losses were only $21 \%$.

Farms with large feed imports had also high costs of plant production. A general value of $\beta=4.6$ was used to estimate $\alpha_{\text {farm }}$. An argument often mentioned in favor of imported feed is that it can improve the diet, resulting in a more efficient feed utilization by the animal (39), that is, a lower $\beta$. What is the consequence of an incorrect value of $\beta$ on the estimate of $\alpha_{\text {farm }}$ ? If $\beta$ has been assumed greater than its true value, then the plant production on the farm has been overestimated and thus $\alpha_{\text {farm }}$ underestimated, and vice versa. There were few estimates of farm-specific $\beta$; one of them was the case of the average commercial Dutch farm, which as mentioned had extraordinary intensive production and inputs compared to the majority of the cases studied. However, the specific $\beta$ of this survey was higher ( $\beta=6.1$, Table 1$)$, than the average, which leads to a somewhat lower value of $\alpha_{\text {farm }}$ than showed in Figure $4 \mathrm{~A}$. The change is, however, too small to weaken the relationship shown in the figure. In conclusion, increased use of imported feed resulted in lower $\mathrm{N}$ efficiency of plant production only or a lower $\mathrm{N}$ recovery by the animals as well. An eventual improvement of the N-use efficiency of the animals (compare for example the two prototypes located side by side in southeastern Norway, Tables 1,2, and 3) was not sufficient to counteract the negative effect on the $\mathrm{N}$ recovery by the plant sector, leading to a lower overall efficiency of the system. This observation confirms the hypothesis suggested by the theoretical analysis that an improvement of the animal sector could easily be cancelled out by a reduced efficiency of the plant sector. Thus, attempts to maximize the $\mathrm{N}$ efficiency of animal feeding should be subordinate to those for a complete utilization of the plant resources available on the farm (e.g., by measures such as intensive rotational grazing and adaptation to a large intake of roughages) and to the use of N-efficient crop rotation systems.

By separating manure storage from the plant sector, it can be shown (not done here for brevity), that in many cases a better recovery of the total plant production on the farm as feed can be even more effective for the $\mathrm{N}$ performance of the whole system than further improvements of the manure storage. Nevertheless, reducing loss of ammonia from animal excrement is one of the most straightforward methods for improving $\mathrm{N}$ recovery by plants.

\section{Conclusion and perspectives}

Several authors $(2,34,40)$ have pointed out the negative effect for the global $\mathrm{N}$ eutrophication of the disassociation of livestock from crop production, which is brought forth by an intensification of animal production in restricted areas and by large transport of feed from "animal-free" regions. It has been estimated that only about $34 \%$ of $\mathrm{N}$ in animal "waste" excreted in the U.S. in 1990 was returned to cropped fields for use as fertilizer (41). This work enables a quantification of the potential $\mathrm{N}$ loss to the environments due to the intensification and specialization of animal production on a limited area. The data for Europe are alarming: the N-use efficiency decreases tremendously as the animal production is intensified by imports of feed and fertilizers. In order to reduce global $\mathrm{N}$ pollution, it is an imperative to distribute animal production more evenly and in relation to the amount of feed that can be produced locally. The problem is of such a magnitude that it is bound to have political implications.

Furthermore, lack of land is not always a problem. Current agriculture throughout Europe is characterized by a concentration of milk production in some regions, and by overproduction, therefore the maintenance of very high output levels per ha is questionable (42). The same author stated that a surplus of 2 million ha agricultural land was expected in Germany. The liberalization of agricultural markets will lead to land surplus in several other European countries. This brings in turn negative environmental aspects, with loss of highly appreciated landscapes and biotopes that have evolved over centuries of cultivation. Thus, when land is available, implementing a more extensive animal management would have positive effects not only on the $\mathrm{N}$ cycle but also on other environmental aspects.

Kohn et al. (43) pointed out that "Because agricultural scientists have specialized rather than integrated the entire system, it has been difficult to demonstrate the overall economic and environmental consequences of management decisions at the whole farm level." This study shows the consequences for the $\mathrm{N}$ surplus alone. It is legitimate to ask whether the focus of the various expertises (in economy, machinery, tillage, crop and animal management, breeding, etc.) on their topics has led to a dissociation of the agroecosystem. It may be that the separate improvement of the single components has increased the total production but not the efficiency of the resources used, due to an unintentional dis-organization of the components of the agroecosystem. The re-integration of the subcomponents in a well functioning unity requires a highly interdisciplinary effort, focused on the performance of the whole system rather than on the separate optimization of the single components.

In conclusion, global $\mathrm{N}$ pollution by dairy farming can be mitigated by the following measures: $i$ ) re-coupling crop production and animal raising side by side; ii) promoting a more extensive farming system, with moderate nutrient inputs, rather than abandoning agricultural land while intensifying dairy production on a smaller area; iii) subordinating the $\mathrm{N}$ efficiency of the herd to that of the plant sector; and $i v$ ) a closer interdisciplinary scientific effort involving all relevant expertises, focused on the performance of the whole from-soil-toanimal system rather than on separate efforts to optimize the single components (44).

\section{References and Notes}

All nitrogenous compounds that are biologically available.

Mosier, A.R., Bleken, M.A., Chaiwanakupt, P., Ellis, E.C., Freney, J.R., Howarth R.B., Matson, P.A., Minami, K., et al. 2001. Policy implications of human-accelerated nitrogen cycling. Biogeochem. 52, 281-320. 
3. Galloway, J.A., and Cowling, E.B. 2002. Reactive nitrogen and the world: 200 years of change. Ambio 31, 64-71.

4. Bleken, M.A. and Bakken, L.R. 1997. The nitrogen cost of food production: Norwegian society. Ambio 26, 134-142.

5. Van Der Hoek, K.W. 1998. Nitrogen efficiency in global animal production. Environ. Pollut. 102, 127-132.

6. Howarth, R.W., Boyer, E.W., Pabich, W.J., and Galloway, J.N. 2002. Nitrogen use in the United States from 1961-2000 and potential future trends. Ambio 31,88-96.

7. Smil, V. 2002. Worldwide transformation of diets, burdens of meat production and opportunities for novel food proteins. Enzyme Microb. Technol. 30, 305-311.

8. Food and Argricultural Organization of the United Nations. 2004. FAOSTAT data (http://apps.fao.org)

9. Council Directive 91/676/EEC 1991. Council Directive of 12 December 1991 Concerning the Protection of Waters Against Pollution from Agricultural Sources (91/676/EEC). Official Journal L 375, 31/12/1991. pp. 1-8.

10. Directive 2000/60/EC 2000. Directive 2000/60/EC of the European Parliament and of the Council of 23 October 2000 Establishing a Framework for Community Action in the Field of Water Policy. Official Journal L 327, 22/12/2000. pp. 1-73.

11. Brouwer, F.M., Godeschalk, F.E., Hellegers, P.J.G.J., and Kelholt, H.J. 1995. Mineral balances at farm level in the European Union. The Hague: Agricultural Economics Research Institute (LEI-DLO), $141 \mathrm{pp}$.

12. Oenema, O., Kros, H., and de Vries, W. 2003. Approaches and uncertainties in nutrient budgets: implications for nutrient management and environmental policies. Eur. J. Agron. 20, 3-16.

13. Olsthoorn, C.S.M., and Fong, N.P.K. 1998. The anthropogenic nitrogen cycle in the Netherlands. Nutr. Cycl. Agroecosyst. 52, 269-276.

14. Bouwman, A.F., and Booij, H. 1998. Global use and trade of feedstuffs and consequences for the nitrogen cycle. Nutr. Cycl. Agroecosyst. 52, 261-267.

15. We follow the terminology of the European Environmental Agency, and losses to both air and water are defined as emissions.

16. Bouwman, A.F., Boumans, L.J.M., and Batjes, N.H. 2002. Estimation of global NH3 volatilization loss from synthetic fertilizers and animal manure applied to arable lands and grasslands. Glob. Biogeochem. Cycles 16. Art. no. 1024 URL/ ISI: 000178887900004.

17. Tainton, N.M. 1974. Effects of different grazing rotations on pasture production. J. Br. Grassl. Soc. 29, 191-202.

18. Korsæth, A., and Eltun, R. 2000. Nitrogen mass balances in conventional, integrated and ecological cropping systems and the relationship between balance calculations and nitrogen runoff in an 8-year field experiment in Norway. Agric. Ecosyst. Environ. 79 199-214

19. Taube, F., and Pötsch, E.M. 2001. On-farm nutrient balance assessment to improve nutrient management on organic dairy farms. Grassland Sci. Eur. 6, 225-234

20. Steinshamn, H., Thuen, E., Bleken, M.A., Brenøe, U.T., Ekerholt, G., and Yri, C. 2004 Utilization of nitrogen $(\mathrm{N})$ and phosphorus $(\mathrm{P})$ in an organic dairy farming system in Norway. Agric. Ecosyst Environ. 104, 509-522.

21. Kaffka, S., and Koepf, H.H. 1989. A case study of the nutrient regime in sustainable farming. Biol. Agric. Hortic. 6, 89-106.

22. Scheringer, J., and Isselstein, J. 2001. Nitrogen budgets of organic and conventional dairy farms in North-West Germany. Grassland Sci. Eur. 6, $284-287$.

23. Chambaut, H., and Le Gall, A. 1998. Mineral balance in dairy farms: surplus levels by type of farm production and its use to advice groups of farmers on environmental topics. Renc. Rech. Ruminants 5, 1-4. (In French).

24. van Gool, B. 2001. Nutrient Account at Farm Level. End report and results from the account year 1999. Sunnhordland Forsøksringen, Seimsfoss. Norway. (In Norwegian).

25. Halberg, N., Kristensen, E.S., and Kristensen, I.S. 1995. Nitrogen turnover on organic and conventional mixed farms. J. Agric. Environ. Ethics 8, 30-51.

26. Dalgaard, T., Halberg, N., and Kristensen, I.S. 1998. Can organic farming help to reduce N-losses? Experiences from Denmark. Nutr. Cycl. Agroecosyst. 52, 277-287.

27. Grignani, C. 1996. Influence of the type of cattle system on nutrient balance at a farm scale in the Po Plain. Rivista di Agromomia XXX, supplement no.3,414 422. (In Italian).

scale in the Po Plain. Rivista di Agronomia XXX, supplement no.3, 414-422. (In Italian).

. Cuttle, S.P. 2002. Nutrient budgets as a tool for researchers and farmers. In: UK Organic Research 2002. Proceedings of the COR Conference, 26-28 March 2002. Powell, J.,
Davies, G., Fowler, S., Hovi, M., Lampkin, N. and Lennartsson, M., Padel, S. et al. Davies, G., Fowler, S., Hovi, M.,
(eds.). Aberystwyth, pp. 169-172.

29. Thuen, E. Steinshamn, H., Bleken, M.A., Brenøe, U, Yri, C., and Ekerholt, G. 2004 Nitrogen $(\mathrm{N})$ and phosphorus $(\mathrm{P})$ utilization in different dairy production systems. In: Early Harvested Forage in Milk and Meat Production. Proceedings of the International Symposium. Nannestad, Norway Oct. 23-24 2003. Garmo, T.H. (ed). Agricultural University of Norway. Department of Animal and Aquacultural Sciences, Ass, pp. 103 113.

30. Aarts, H.F.M., Habekotté, B., and van Keulen, H. 2000. Nitrogen (N) management in the 'De Marke' dairy farming system. Nutr. Cycl. Agroecosyst 56, 231-240.

31. Verbruggen, I., Carlier, L., and van Bockstaele, E. 1994. Surplus of nutrients on dairy farms in Belgium. In: Grassland and society. Proceedings of the 15th General Meeting of the European Grassland Federation Wageningen 6-9 June 1994. 't Mannetje, L. and the European Grassland Federation Wageningen 6-9 June 1994. 't Man
Frame, J. (eds). Wageningen Pers. Wageningen, Netherland, pp. 463-465.

32. Barrett, K., Seland, Ø. Foss, A., Mylona, S., Sandnes, H., Styve, H., and Tarrasón, L. Barrett, K., Seland, Ø., Foss, A., Mylona, S., Sandnes, H., Styve, H., and Tarrasón, L.
1995. European Transboundary Acidifying Air Pollution. Ten years calculated fields and budgets to the end of the first Sulphur Protocol. EMEP/MSC-W Report 1/95.

33. SAS Institute Inc. 1989. SAS/STAT User's Guide, Version 6 (4th ed.), Vol. 2, 1673 pp.

34. Tamminga, S. 2003. Pollution due to nutrient losses and its control in European animal production. Livest. Prod. Sci. 84, 101-111.

35. Watson, C.A., Bengtsson, H., Ebbesvik, M., Loes, A.K., Myrbeck, A., Salomon, E., Schröder, J., and Stockdale, E.A. 2002. A review of farm-scale nutrient budgets for organic farms as a tool for management of soil fertility. Soil Use Manage. 18, 264-273.

36. Swensson, C. 2003. Analyses of mineral element balances between 1997 and 1999 from dairy farms in the south of Sweden. Eur. J. Agron. 20, 63-69.

37. Schröder, J.J., Aarts, H.F.M., ten Berge, H.F.M., van Keulen, H., and Neeteson, J.J. 2003. An evaluation of whole-farm nitrogen balances and related indices for efficient nitrogen use. Eur. J. Agron. 20. 33-44.

38. AFRC 1993. Energy and Protein Requirements of Ruminants. An advisory manual prepared by the AFRC Technical Committee on Responses to Nutrients. CAB International, Wallingford, UK. 159 pp.

39. Tamminga, S. 1996. A review on environmental impacts of nutritional strategies in ruminants. J. Anim. Sci. 74, 3112-3124.

40. Granstedt,, A. 2000. Increasing the efficiency of plant nutrient recycling within the agricultural system as a way of reducing the load to the environment-experience from Sweden and Finland. Agric.Ecosyst. Environ. 80, 169-185.

41. NRC ( National Research Council) 1993. Soil and Water Quality: An Agenda for Agriculture. Committee on Long-Range Soil and Water Conservation. Board on Agriculture. Committee on Long-Range Soil and Water Conservation. Board on
Agriculture. National Research Council. National Academy Press, Washington DC. 542 pp.

42. Weissbach, F., and Ernst, P. 1994. Nutrient budgets and farm management to reduce nutrient emissions. In: Grassland and society. Proceedings of the 15th General Meeting of the European Grassland Federation Wageningen 6-9 June 1994. 't Mannetje, L. and Frame, J. (eds). Wageningen Pers. Wageningen, Netherland, pp. 343-360.
43. Kohn, R.A., Dou, Z., Ferguson, J.D., and Boston, R.C. 1997. A sensitivity analysis of nitrogen losses from dairy farms. J. Environ. Manage. 50, 417-428.

44. The authors thank Hélène Chambaut, Carlo Grignani, Sylvie Hacala, and Erich Pötsch for help in the collection of data. Financial support from the Norwegian Research Council is acknowledged.

45. First submitted 26 Oct. 2004. Revised manuscript received 9 May 2005. Accepted for publication 15 June 2005 .

Marina Azzaroli Bleken is an associate professor in the Department of Plant and Environmental Sciences, Norwegian University of Life Sciences. Her research is focused on the dynamics of plant-soil-environment interactions and on the utilization of plant products in the food chain. Her address: Department of Plant and Environmental Sciences, Tårnbygningen, Norwegian University of Life Sciences, PB 5003, 1432 Ås, Norway. marina.bleken@umb.no

Håvard Steinshamn has a dr. scienct. degree from the Department of Horticulture and Crop Sciences, Agricultural University of Norway. From 1998-2004 he was researcher at the same department and since 2004 researcher at the Norwegian Centre of Ecological Agriculture, Tingvoll, Norway. Scientific interests are grassland production and farming, dairy production systems and environmental assessments. His address: Norwegian Centre for Ecological Agriculture, Tingvoll gard, N-6630 Tingvoll, Norway.

Sissel Hansen has a dr. scienct. degree from the Institute of Biotechnological Science, Agricultural University of Norway. Since 1993 she has been researcher at the Norwegian Centre of Ecological Agriculture, Tingvoll, Norway. Her main work field is nutrient cycling within organic farming systems and environmental assessments. Her address: Norwegian Centre for Ecological Agriculture, Tingvoll gard, N-6630 Tingvoll, Norway. 